\title{
THE COMMON DATE PALM
}

(Phoenix dactylifera.)

IN the October numbers of the Revue des Cultures Coloniales M. Jules Grisard has compiled from various sources of information two very interesting articles on the products and uses of the date palm, to which I add information of my own collecting in Tunis and Central Africa.

Although the range of the cultivated date palm includes India, Persia, and Arabia on the east and southern Spain and the Canary Islands on the west, it is particularly associated in the minds of most people with the harsh North African landscapes, in which it forms so striking and beautiful a feature, while kindred wild species are found throughout tropical Africa. In this connection it may be fitly discussed in the Joumal of the African Society.

The stem of the young date palm does not begin to grow visibly till the fourth or fifth year after it has been planted. "Until then (writes Poiret) the leaves grow upward from a thick shoot like an oval bulb, which is renewed every year. When this reaches the girth which the tree is destined to assume it pushes itself by degrees above ground, and shows the beginning of a trunk, composed entirely of the joined bases of the old fronds. The trunk increases in height as the leaves drop off ..... their bases remain, and form the projecting ridges which the cultivator-aiding nature a little-renders suitable to serve as footholds for those who have to pick the dates." When full grown the average height of this slender trunk is perhaps a little less than fifty feet, but in many cases this measurement is greatly exceeded. Though not usually esteemed as a first-class building timber, the straight stems of the 
date palm furnish ready-made rafters and supports for houses, ${ }^{1}$ and the massive doorways at the entrances of some Arab towns are likewise built of palm trunks. These are still more useful for irrigation purposes when hollowed out and made into conduits for water, or when driven into the treacherous sand as stakes and piles to support the sides of wells. As fuel the wood of this tree burns slowly and without much flame, but gives off great heat.

The sap drawn from the trunk is a pale-grey liquid, looking rather like barley water. When fresh from the tree it is very sweet but a most agreeable beverage. This is the lagrni (لقهي) of the Arabs, the "milk" of the palm tree, which very quickly ferments and becomes palm "wine."

M. de Kerkove de Denterghen, a well-known writer on this subject, says: "A few hours after the sap has been collected a faint hissing sound is heard in the jar. The fermentation begins to work : the liquid sparkles, and a light froth forms round the rim. In this condition palm wine rivals the best brands of champagne, and cheers without inebriating. But this phase is a passing one: a few hours more, and the 'champagne' has become a whitish beer thick as milk, with a slightly acid flavour. Give it a wide berth then, for it enlivens no more but is as intoxicating as brandy."

This is the most ephemeral of wines. The sweet refreshing drink, the sparkling champagne, the heady beer soon become a muddy, nauseous liquid, full of little red flies. There is an Arab saying to the effect that you can only drink the palm wine under the shade of the tree which has furnished it.

The sap is generally obtained by cutting the crown of the tree and hollowing out a depression, into which the sap flows and is thence conveyed by several channels into the jars prepared for it. The flow of sap lasts for six or eight weeks, though diminishing in quantity each day. This process, which entails the death of the tree is not so profitable as that which prevails at Gabes, in Tunis, where the sap is drawn off by making a circular incision in the middle of the

1 In Uganda the stems of the wild date ralm are used as pillars to support the light thatched roofs of churches and other comparulively lufty native buildings. 
crown of leaves, avoiding as much as possible the heart of the tree and filling in the wound each day. In this way the palm tree yields two gallons of lagmi in twenty-four hours; and this goes on at intervals for three or four months, after which the wound is left to heal and the tree remains perfectly healthy, though it does not bear fruit during the year in which the incision has been made. This same operation can be performed three times on the same tree at intervals of two years.

The membrane of coarse fibre in several layers which covers the bases of the palm-fronds is used in making ropes, baskets, mats, \&c., and, mixed with camel's hair, makes a strong cloth for the caravan tents of the desert nomads. From the dried stalks of the fronds are made big cages for quails and other wild birds, and palisades of spikes along the top of the mud walls round estates in the Saharan oases; while in the Gulf of Gabes the fisheries are enclosed by closely woven fences of these tough and flexible branches.

The full-grown leaves are used to shelter plantations of young palm trees from the sand and wind; the folded, sharply pointed leaves round the crown of the tree are useful as flywhisks. The very young leaves and shoots are cooked with meat and eaten as a vegetable. So also is the great terminal shoot at the head of the tree. This last, with its scaly white covering, is said to resemble almonds or chestnuts in flavour. As the loss of this terminal shoot entails the death of the tree, it is only cut off from palms which have been blown down by the wind, or from those male trees which have to be weeded out from a plantation because they predominate too much over the females $;^{1}$ or these last may be sacrificed when through age they have become unfruitful.

The blossom, the pollen, and the resin of Phoenix dactylifera, and even the kernels of its fruit, ${ }^{2}$ are used as remedies, real or imaginary, for various complaints in different parts of Africa.

1 Under natural conditions about 70 per cent. of the trees are male.

2 According to Dr. Bertherand, the dried powder of crushed date stones is a genuine remerly for dyspepsia and diarrhoea.

In some places dale stones are put to a less innocent wse, being roasted and ground and passed off as coffee, which thay then resemble in appearance though not in smell. This form of adulteration is not unlenown in Europe as well as in Africa 
The flowers of the male date palm, for instance, are eaten by some Algerian women as a cure for sterility.

But of all the various useful products of this wonderful tree the dates, of course, are the most important. Each female tree will produce from eight to ten long stalks of inflorescence, from which grow subsequently the clusters of dates. There are hundreds of different varieties of dates, and in the lands where they grow they can be eaten fresh for half the year.

In North Africa the Daglat-nür is particularly esteemed for the transparency and delicate flavour of its fruit, and is picked with particular care to avoid bruising. The Ghar dates are too soft for exportation, but (mixed sometimes with other varieties) are thrown into broad jars or pans for the extraction from them of sugar (often called "honey") and alcohol. ${ }^{1}$ The pickers press down the dates with their feet, pouring on them from time to time a little water, till they are quite solid. A hole in the bottom of the vessel drains off the sugar in the form of a syrup, which is subsequently mixed with butter. When the great jars or pans are full of squashed dates they are covered over with palm leaves and kept till the end of the winter, by which time the paste has become so hard that it requires some strength to drive into it the antelope horn generally used for this purpose. The Dagla baida dates, picked while still green, are more suitably dried by the ordinary method of exposure to the sun on extended hurdles of interwoven palm fronds. Under this treatment they soon become reddish and semi-transparent, and much sweeter in taste. In Egypt the early Red dates (Balah hayani), and the honeyed Yellow dates (Balah amalat) are most commonly seen in the markets. The Arabs prefer completely dried dates as a daily article of diet, as they are cheaper and more portable than the fresh fruit. Sheep and horses are said to show a similar preference for the dried dates, which as fodder can take the place of the Drinn or Halfa grass when the steppe land merges into the sandy desert; while, according to Dr. Bertherand, a diet of date stones is calculated to greatly improve both the quantity and quality of the milk of goats.

1 This aloohol (not to be confounded with palm "wine") is distilled from the pulp of the dates, and, mixed with different aromatic herbs, is made into liqueurs, which are much appreciated by the Arabe. 
The date barvest is attended by considerable risk to life and limb, and the proprietors of palm groves take care to interest the pickers in their work by giving them a share of the proceeds. Those who are to gather the ripe date-stalks pass round their loins and round the palm stem a strong girdle of cords made from the fibre or the roots of the date palm itself, and this allows them to lean backwards, holding on with their toes to the rough ridges of the trunk, while with their hands they cautiously shift the position of the cords, which prevent them from falling as they work their way up the tree.

This difficult and perilous ascent seems to have made a deep impression on the mind of the Ancients, for it is from them that we have borrowed the palm as a symbol of victory. This tree, in fact, more than any other embodies many ideas in many religions-Pagan and Muhammadan ${ }^{1}$ as well as Christian-and also played a great part in early Eastern architecture in giving birth to beautiful conceptions of combined strength and height and grace.

As is well known, the female date palms have as a rule to be artificially fertilised in order to produce eatable fruit. This operation takes place from February to April, according to climate and locality. The ripe spadices of the male palm are plucked with the greatest care (so as to lose none of their fertilising dust), and are divided into small fragments, each composed of ten or twelve flowers. Placing them in the hood of his bürnous, the Arab then climbs to the top of a female tree, where, after having cut the spathe with a knife, he inserts one of the small fragments of the male tree, first shaking it thoroughly over the crown of the female. One "stud" male palm suffices for the fertilisation of forty or fifty female trees.

M. Hariot assures us in Le Jardin (June 2, 1902) that the inhabitants of certain oases in the Sahara believe that man can intervene to change the sex of the young date palm. The process would seem to consist in tearing off all the leaves from the two- or three-year-old stump. This causes a concentration of sap, which is more necessary to the vital functions of the female

1 The wild date palm is the totem of one of the Bagand clens called in the language of Uganda Lukindo. It may be mentioned too that some of the Moslems of the Sahan still mate rosaries out of dete stones. 
plant than to those of the superfluous male. M. Hariot adds : "No scientific objection can be urged against this assertion, especially as in the young plants the organs are not yet differentiated for their respective functions."

The welfare of the date palm depends mainly on two conditions: dry heat and abundant irrigation at its roots. The presence of humidity in the atmosphere is the only reason why it does not usually thrive near the sea; for the action of salt and salt water on its roots is not only harmless but positively beneficial. Some of the finest kinds of dates are produced in the country of the Shatts or dried up salt lakes in the south of Tunis, where the Sahara is now irrigated by the numerous hot and cold springs which once flowed regularly into these curious depressions-now silted up and left dry for the greater part of the year, but once probably a continuous arm of the Mediterranean. ${ }^{1}$ Systematic manuring, of course, has a marked effect on the growth and fertility of the date palm.

Under favourable conditions these trees have been known to live for two hundred years; but after a century of existence they cease to bear fruit.

Alex. Johnston.

\footnotetext{
1 See the Consul-General's Report to the Foreign Office on the Regency of Tunis, published as a Blue Book in 1898 (France, No. 3). The same writer makes the saggestion that the Lotus, which appealed so much to the teste of the Argoneuts, was really the date, and that the mystic island of the Lotus-Eaters was Jerba, off the South-East Coast of Tunis, where the date palm reaches its perfection.
} 